\title{
Relationships of Frankia Isolates Based on Deoxyribonucleic Acid Homology Studies
}

\author{
CHUNG SUN AN, ${ }^{1}$ W. STUART RIGGSBY,${ }^{2}$ AND BETH C. MULLIN ${ }^{1 *}$ \\ Department of Botany ${ }^{1}$ and Department of Microbiology, ${ }^{2}$ University of Tennessee, Knoxville, Tennessee 37996-l100
}

\begin{abstract}
A molecular approach was used to examine the genetic relatedness of 19 Frankia isolates by measuring the extent of deoxyribonucleic acid-deoxyribonucleic acid homology and the fidelity of hybrid duplex molecules. The Frankia isolates examined were divided into two groups based on the results of hybridization tests. The members of genogroup 1, consisting of isolates from Alnus, Myrica, and Comptonia host plants, exhibited high levels of homology (67.4 to $\mathbf{9 4 . 1 \%}$ ) with strain ArI4, an isolate from Alnus rubra. Isolates from Elaeagnus, Ceanothus, Purshia, and Casuarina and isolate AirI2 from Alnus did not exhibit significant homology (less than 39\%) with strain ArI4. None of the strains showed a high degree of homology with strain EuI1a (less than $33 \%$ ), an isolate from Elaeagnus umbellata. Among the isolates not belonging to genogroup 1, subgroupings seemed to exist, as evidenced by a very high level of homology $(97 \%)$ between two isolates from Casuarina, strains D11 and the G2, but a low level of homology (27\%) between other strains and strain G2. Thermal stability studies of the hybrid deoxyribonucleic acids which showed high levels of homology revealed an average mismatch of $3 \%$, whereas the low-homology duplexes exhibited about $5 \%$ mismatch. The genome molecular weights of two probe Frankia strains, strains ArI4 and EuIla, were $8.3 \times 10^{9}$ and $6.0 \times 10^{9}$, respectively.
\end{abstract}

Since the first confirmed isolation of a nitrogen-fixing Frankia endophyte from Comptonia root nodules (11), more than 50 strains from 20 different plant species have been isolated (2). The availability of increasing numbers of isolates has made it possible to examine various aspects of these endophytes grown in vitro.

Morphologically, there appear to be no fixed distinctive differences among the isolates other than pigmentation and the occurrence of vesicles in culture. The size, shape, and number of the sporangia, as well as the overall density of the colonies, depend largely on the culture conditions $(7,16)$. Biochemical studies (18) also have demonstrated a uniformity among Frankia isolates in terms of cell wall composition (type III) and phospholipid pattern (type I), although their cell sugar patterns vary widely. Based on serological (3), physiological (19), and cross-inoculation studies $(5,7,16)$, the isolates can be divided into at least two groups. Generally, the isolates from Alnus, Myrica, and Comptonia belong to the same group (serogroup I, physiological group B), whereas the isolates from Elaeagnus, Ceanothus, Purshia, and Casuarina form a separate group (serogroup II, physiological group A).

Despite these studies, there are no consistently useful taxonomic criteria for proper classification of Frankia isolates. Accordingly, the principal purpose of this study was to use a molecular approach to examine the genetic relatedness of Frankia isolates. This approach was based on the base composition of deoxyribonucleic acid (DNA) (1), the degree of DNA-DNA hybridization, and the thermal stability of the hybrid DNA duplexes.

\section{MATERIALS AND METHODS}

Organisms and culture conditions. The 19 strains used in this study, their sources, and the media on which they were grown are shown in Table 1. The methods used to culture and harvest cells have been described previously (1).

Extraction and in vitro labeling of DNA. DNA was extracted as described by An et al. (1), and DNAs to be used for probes were labeled in vitro by nick translation (25),

* Corresponding author. using ${ }^{3} \mathrm{H}$-labeled deoxycytidine triphosphate (Amersham Corp.). The other reagents used for labeling were obtained in the form of a nick-translation kit (kit NEX-004E; New England Nuclear Corp.) and were used according to the directions of the supplier. A typical $30-\mu$ l reaction mixture consisted of $0.6 \mathrm{nM}^{3} \mathrm{H}$-labeled deoxycytidine triphosphate, $500 \mathrm{ng}$ of DNA, $4 \mu \mathrm{l}$ of a deoxyribonucleoside triphosphate mixture (lacking deoxycytidine triphosphate), $2 \mu$ l of DNA polymerase I, and $2 \mu \mathrm{l}$ of deoxyribonuclease I. After $2 \mathrm{~h}$ of incubation at $15^{\circ} \mathrm{C}$, the reaction was stopped by adding $3 \mu l$ of $200 \mathrm{mM}$ ethylenediaminetetraacetate. To separate labeled DNA from unreacted nucleotides, the entire reaction mixture was layered onto the top of a 1-ml bed of Sephadex G-50 in a 3-ml plastic syringe, and chromatography was carried out by washing the column with elution buffer $[0.25 \mathrm{M} \mathrm{NaCl}$, $0.05 \mathrm{M}$ tris(hydroxymethyl)aminomethane, $\mathrm{pH} 7.9,0.5 \%$ sodium dodecyl sulfate, $2 \mathrm{mM}$ ethylenediaminetetraacetate]. About $30100-\mu l$ fractions were collected, and the radioactivity of $5 \mu \mathrm{l}$ of each fraction was estimated by using a scintillation counter. Fractions which corresponded to the first peak of radioactivity were pooled and used as the DNA probe.

Preparation of DNA mixtures for reassociation. Typically, a mixture of ${ }^{3} \mathrm{H}$-labeled DNA and $200 \mu \mathrm{g}$ of unlabeled DNA (about 1:4,000, wt/wt) was sheared and purified, and the sizes of the resulting DNA fragments were determined electrophoretically by a modification of the methods described by Riggsby et al. (26). The DNA was sheared for 30 min at $45,000 \mathrm{rpm}$ in a Virtis model $45 \mathrm{~K}$ homogenizer, resulting in a fragment size of approximately 300 base pairs.

Reassociation (hybridization) and hydroxyapatite chromatography. Samples containing sheared, purified, labeled and unlabeled DNAs in $0.12 \mathrm{M}$ sodium phosphate buffer ( $\mathrm{pH}$ 6.8) were sealed in sterile siliconized $20-$ to $100-\mu$ l capillary tubes. Sample sizes ranged from 10 to $70 \mu \mathrm{l}$ depending on the specific activity of the labeled DNA. To dissociate the DNAs, the capillary tubes were heated to $115^{\circ} \mathrm{C}$ in an ethylene glycol-water mixture for $10 \mathrm{~min}$ and placed immediately in a water bath set at the reassociation temperature. The reassociation temperature was $64.5^{\circ} \mathrm{C}$ for Escherichia coli DNA and $74.5^{\circ} \mathrm{C}$ for Frankia DNAs. These tempera- 
TABLE 1. Frankia isolates used in this study

\begin{tabular}{|c|c|c|c|c|}
\hline \multirow{2}{*}{ Strain } & \multicolumn{2}{|c|}{ Host plant } & \multirow{2}{*}{ Source } & \multirow{2}{*}{ Medium ${ }^{a}$} \\
\hline & Species or subspecies & Collection site & & \\
\hline$\overline{\mathrm{ACN}} 1^{\mathrm{AG}}$ & Alnus viridis subsp. crispa & Quebec, Canada & M. Lalonde & $\mathrm{T} / \mathrm{C}$ \\
\hline AGNlg & Alnus glutinosa & Holland & M. Lalonde & $\mathrm{T} / \mathrm{C}$ \\
\hline $\mathrm{AGN} 1_{\mathrm{ExO}}{ }^{\mathrm{AG}}$ & Alnus glutinosa & & M. Lalonde & $\mathrm{T} / \mathrm{C}$ \\
\hline Airl1 & Alnus incana subsp. rugosa & Vermont & M. P. Lechevalier & $\mathrm{T} / \mathrm{C}$ \\
\hline Airl2 & Alnus incana subsp. rugosa & Vermont & M. P. Lechevalier & $\mathrm{YC}_{\mathrm{z}}$ \\
\hline $\mathrm{ARbN} 4 \mathrm{~b}$ & Alnus rubra & Oregon & M. Lalonde & $\mathrm{T} / \mathrm{C}$ \\
\hline ArI4 & Alnus rubra & Washington & D. Baker & $\mathrm{T} / \mathrm{C}$ \\
\hline Avcl1 & Alnus viridis subsp. crispa & Ontario, Canada & D. Baker & $\mathrm{T} / \mathrm{C}$ \\
\hline CaIl & Ceanothus americanus & & M.P. Lechevalier & $\mathrm{YC}_{\mathrm{z}}$ \\
\hline CpIl & Comptonia peregrina & Massachusetts & D. Baker & $\mathrm{FB}$ \\
\hline D11 & Casuarina equisetifolia & Senegal & Y. Dommergues & $\mathrm{YC}_{\mathrm{z}}$ \\
\hline $\mathrm{G} 2$ & Casuarina equisetifolia & Guadeloupe & Y. Dommergues & $\mathrm{YC}_{\mathrm{z}}$ \\
\hline MpI1 & Myrica pensylvanica & Massachusetts & M. P. Lechevalier & $\mathrm{T} / \mathrm{C}$ \\
\hline PtIl & Purshia tridentata & & D. Baker & $\mathrm{YC}_{\mathrm{z}}$ \\
\hline EuIla & Elaeagnus umbellata & & D. Baker & $\mathrm{FB}$ \\
\hline EUN1fS20 & Elaeagnus umbellata & Illinois & M. Lalonde & Qmod \\
\hline EUN1wb & Elaeagnus umbellata & Illinois & M. Lalonde & Qmod \\
\hline EAN $1^{\text {EA }}$ & Elaeagnus angustifolia & & M. Lalonde & Qmod \\
\hline $\mathrm{EAN} 1_{P E C}{ }^{\mathrm{EA}}$ & Elaeagnus angustifolia & Ohio & M. Lalonde & Qmod \\
\hline
\end{tabular}

${ }^{a} \mathrm{~T} / \mathrm{C}$, Tween-casein medium; $\mathrm{YC}_{\mathrm{z}}$, Czapek broth supplemented with yeast extract (5); FB, Frankia broth (4); Qmod, Qmod medium (16).

tures were chosen to obtain optimum reassociation rates according to the criteria of Wetmur and Davidson (30). To measure reassociation kinetics, the capillary tubes were removed from the water bath at different times (at $C_{0} t$ values of 0.05 to $200 \mathrm{~mol} \cdot \mathrm{s} /$ liter) and transferred immediately to a dry ice-ethanol bath. The contents of each capillary tube were diluted into $1 \mathrm{ml}$ of $0.12 \mathrm{M}$ sodium phosphate buffer (pH 6.8) containing $50 \mu \mathrm{g}$ of calf thymus DNA per $\mathrm{ml}$ and frozen for analysis later. These latter procedures were designed to discourage further reassociation in subsequent manipulations during hydroxyapatite fractionation. For hybridization reactions, reassociation was stopped at a $\mathrm{C}_{0} \mathrm{t}$ value of $100 \mathrm{~mol} \cdot \mathrm{s} /$ liter, at which point more than $80 \%$ of the Frankia probe DNA had become reassociated (Fig. 1). To distinguish unreacted, single-stranded DNA (ssDNA) from reacted, double-stranded DNA (dsDNA), hydroxyapatite chromatography was carried out as described previously (26), and the data were analyzed by the computer program developed by Pearson et al. (24). The results of each hybridization test were normalized to the extent of the

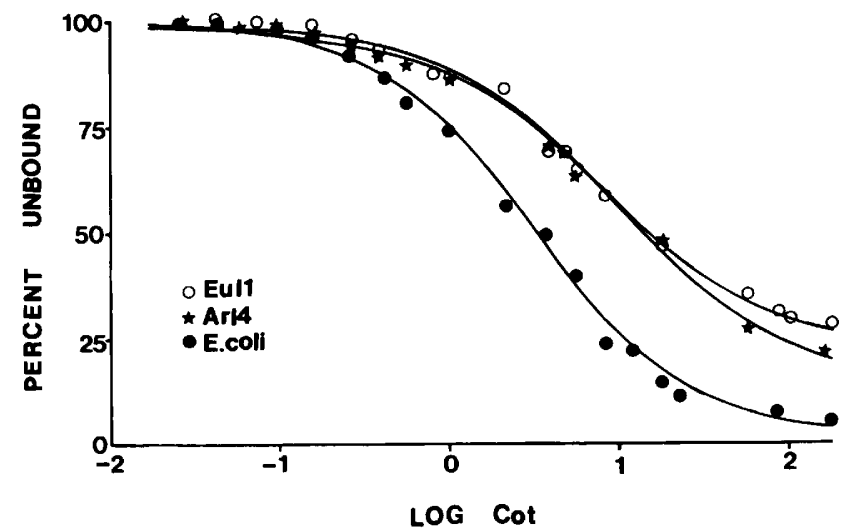

FIG. 1. Reassociation kinetics of DNAs from two frankiae, strains ArI4 and EuIla, and $E$. coli assayed by hydroxyapatite chromatography. The lines represent the best fits to the data generated by the computer program described by Pearson et al. (24). homologous reaction (77\% for strain ArI4 and $76 \%$ for strain EuIla). Self-reassociation of labeled DNA (the extent of reassociation for a reaction mixture consisting of only labeled DNA) was less than $1 \%$ (data not shown).

Window diagram for thermal elution studies. The reliability of the hydroxyapatite technique for assessing the thermal stability of DNA-DNA duplexes depends strongly on the choice of the ionic environment and temperature range at which the studies are carried out. In order to determine the proper criteria for thermal elution studies, a partial window diagram was constructed by using the protocol of Martinson and Wagenear (21). Thermal chromatography of strain Arl4 DNA was carried out by using several different concentrations of potassium phosphate buffer (range, 20 to $100 \mathrm{mM}$ ) made by mixing equimolar amounts of monobasic and dibasic potassium phosphate in $50 \%(\mathrm{vol} / \mathrm{vol})$ formamide. For each buffer system, successive thermal elutions were carried out at intervals of $3^{\circ} \mathrm{C}$ from 40 to $95^{\circ} \mathrm{C}$. Hydroxyapatite chromatography was performed as described above. The fractions eluted at each temperature were collected and assayed for radioactivity. The thermal elution temperature $\left[T_{m(e)}\right]$ for each concentration of potassium phosphate buffer was calculated from a graphic representation by interpolation of the temperature at which $50 \%$ of the radioactivity was eluted from the column. A partial window diagram was obtained by plotting $T_{m(e)}$ on a linear scale against concentration of potassium phosphate buffer on a logarithmic scale (22).

\section{RESULTS}

Reassociation of Frankia DNA. To measure the genome size of Frankia, as well as to define the reaction system for hybridization tests, reassociation kinetics experiments were carried out by using DNAs from two representative strains, strains ArI4 and EuIla. The reassociation data are plotted in Fig. 1, in which the percentage of DNA not bound to hydroxyapatite is plotted as a function of the logarithm of $\mathrm{C}_{0} \mathrm{t}(10)$. Data points for each DNA are distributed along the lines, which are the best-fit second-order kinetics curves for each data set generated by the computer program (24). Although substantial amounts of total DNA did not partici- 
TABLE 2. Reassociation kinetics data and genome molecular weights

\begin{tabular}{lcccccc}
\hline Strain & $\begin{array}{c}\text { Fraction of } \\
\text { DNA } \\
\text { reassociated }^{a}\end{array}$ & $\begin{array}{c}K_{\text {obs }} \\
(\text { liter/ } \\
\text { mol } \cdot \mathrm{s})^{h}\end{array}$ & $\begin{array}{c}K_{\text {pure }} \\
\text { (liter/ } \\
\text { mol } \cdot \mathrm{s})^{c}\end{array}$ & $\begin{array}{c}\text { Pure } \\
\mathrm{C}_{0} \mathrm{t}_{1 / 2} \\
(\mathrm{~mol} \cdot \mathrm{s} / \\
\text { liter })^{d}\end{array}$ & $\begin{array}{c}\text { Root } \\
\text { mean } \\
\text { square } \\
\text { error }(\%)^{c}\end{array}$ & $\begin{array}{c}\text { Genome } \\
\text { mol wt } \\
\left(\times 10^{9}\right)^{f}\end{array}$ \\
\hline ArI4 & 0.774 & 0.112 & 0.144 & 6.94 & 1.74 & 8.3 \\
Eul1a & 0.729 & 0.141 & 0.194 & 5.15 & 1.57 & 6.0 \\
E. coli & 0.967 & 0.309 & 0.313 & 3.13 & 3.47 & $2.8^{g}$ \\
\hline
\end{tabular}

${ }^{a}$ Determined by using unconstrained one-component conditions. The number of data points was 17 for strain ArI4, 18 for strain EuIla, and 19 for E. coli. ${ }^{b}$ Observed rate constant.

Pure rate constant (corrected values for the relative fraction of the total DNA reacted).

${ }^{d} \mathrm{C}_{0} \mathrm{t}_{1 / 2}$ for pure DNA; calculated from $1 / K_{\text {pure }}$.

${ }^{e}$ Root mean square deviation of the data points from the curve.

${ }^{f}$ Calculated from the following equation: genome $($ Frankia $)=$ genome $(E$. coli) $\times$ (pure $\mathrm{C}_{0} \mathrm{t}_{1 / 2}$ for Frankia/pure $\mathrm{C}_{0} \mathrm{t}_{1 / 2}$ for $E$. coli $)$.

* Data from reference 20

pate in reassociation, the reactions were essentially completed between $\mathrm{C}_{0} \mathrm{t}$ values of 1 and $100 \mathrm{~mol} \cdot \mathrm{s} / \mathrm{liter}$.

The kinetic parameters derived from these data are summarized in Table 2, along with the calculated genome sizes. Pure rate constant values of 0.194 and 0.144 were used to calculate the genome size of each Frankia isolate based on a $\mathrm{C}_{0} \mathrm{t}_{1 / 2}$ value of $3.13 \mathrm{~mol} \cdot \mathrm{s} / \mathrm{liter}$ for $E$. coli. The calculated genome molecular weights were $6.0 \times 10^{9}$ and $8.3 \times 10^{9}$ for strains EuIla and ArI4, respectively, based on a genome molecular weight of $2.8 \times 10^{9}$ for $E$. coli $(20)$. The differences between these two values are largely attributable to the last few data points in Fig. 1. Since the data points are largely overlapping over most of the course of reassociation, we do not attach any significance to the difference in measured genome molecular weights.

DNA-DNA hybridization. To measure the genetic similarities among the 19 Frankia strains, DNA-DNA hybridization

TABLE 3. Hybridization of the DNAs of Frankia isolates

\begin{tabular}{lcc}
\hline & \multicolumn{2}{c}{$\%$ Hybridization with: } \\
\cline { 2 - 3 } Strain $^{a t}$ & $\begin{array}{c}\text { Strain } \\
\text { ArI4 }\end{array}$ & $\begin{array}{c}\text { Strain } \\
\text { Eulla }\end{array}$ \\
\hline Genogroup 1 & & \\
ArI4(= DDB 010210) & $100(77)^{c}$ & \\
ARbN4b & $94 \pm 4$ & 20 \\
ACN1 & $90 \pm 7$ & 30 \\
AGN1g & $81 \pm 5$ & \\
CpI1 & $81 \pm 2$ & 14 \\
AGN1 ExO AG & $79 \pm 7$ & \\
MPI1(= LLR 162001) & $72 \pm 5$ & \\
AirI1(= LLR 01321) & $72 \pm 1$ & \\
AvcI1(= DDB 010110) & $67 \pm 5$ & $100(76)^{c}$ \\
Strains not in geno- & & 33 \\
group 1 & & 27 \\
EuI1a(= DDB 130110) & 30 & 22 \\
CaI1(= LLR 03011) & 26 & 19 \\
G2(= ORS 020604) & 36 & 15 \\
D11(= ORS 020602) & 29 & 13 \\
PtI1(= DDB 170110) & 36 & \\
EAN EEC & 39 & \\
EUN1fS20 & 18 & \\
AirI2(= LLR 01322) & 27 & \\
EAN1EA & 21 & \\
EUN1wb & 28 & \\
\hline
\end{tabular}

${ }^{a}$ New designations are given in parentheses (D. Baker and M. P. Lechevalier, personal communication).

${ }^{b}$ Genogroup 1 strains showed more than $65 \%$ homology with strain Arl4, and all other strains showed less than $40 \%$ homology.

c Values normalized to homologous reactions.
TABLE 4. DNA-DNA hybridization among some strains not in genogroup 1

\begin{tabular}{|c|c|c|c|c|}
\hline \multirow[b]{2}{*}{ Strain } & \multirow{2}{*}{$\begin{array}{l}\text { Host plant } \\
\text { genus }\end{array}$} & \multicolumn{3}{|c|}{$\%$ hybridization with:" } \\
\hline & & $\begin{array}{l}\text { Strain } \\
\text { EuIla }\end{array}$ & $\begin{array}{l}\text { Strain } \\
\text { CaI1 }\end{array}$ & $\begin{array}{c}\text { Strain } \\
\text { G2 }\end{array}$ \\
\hline Eulla & Elaeagnus & 100 & & \\
\hline CaI1 & Ceanothus & 33 & 100 & \\
\hline G2 & Casuarina & 27 & 47 & 100 \\
\hline D11 & Casuarina & 22 & 60 & 97 \\
\hline PtI1 & Purshia & 19 & 38 & 27 \\
\hline
\end{tabular}

${ }^{a}$ Values normalized to homologous reactions.

tests were carried out by using labeled strain ArI4 and EuI1a DNAs as probes. As Table 3 shows, Frankia strains could be divided into two major groups based on DNA-DNA homology data. Genogroup 1 strains had high levels of homology with strain ArI4 (range, 67 to 94\%; average, 80\%). On the other hand, the remaining strains had low levels of homology with strain ArI4 (range, 18 to $39 \%$; mean, 29\%). When strain EuIla DNA was used as a probe, however, none of the other Frankia strains was found to have a high degree of homology. The highest homology value obtained with this probe was less than $33 \%$. As a group, these strains exhibited slightly less homology with strain EuIla than genogroup 1 strains did.

Based on these results, genogroup 1 strains seemed to be very closely related to each other and to form a homogeneous group, whereas the remainder of the strains were not closely related to either strain EuIla or strain ArI4. To test for the possibility of homology groups other than genogroup 1 , two additional strains, strains CaI1 and G2, were used to prepare DNA probes for hybridization tests. As Table 4 shows, when strain Cal1 DNA was used as a probe, two isolates from Casuarina showed moderate degrees of homology (mean, 54\%), whereas strain PtIl showed a low degree of homology $(38 \%)$. When strain G2 DNA was used as a probe, strain D11 showed very high homology $(97 \%)$, but strain PtI1 exhibited only a low level of homology (27\%). Thus, strains G2 and D11 were assigned to genogroup 2.

Window diagram and thermal elution studies. In order to lower the $T_{m(e)}$ of duplex DNA, organic solvents (formamide

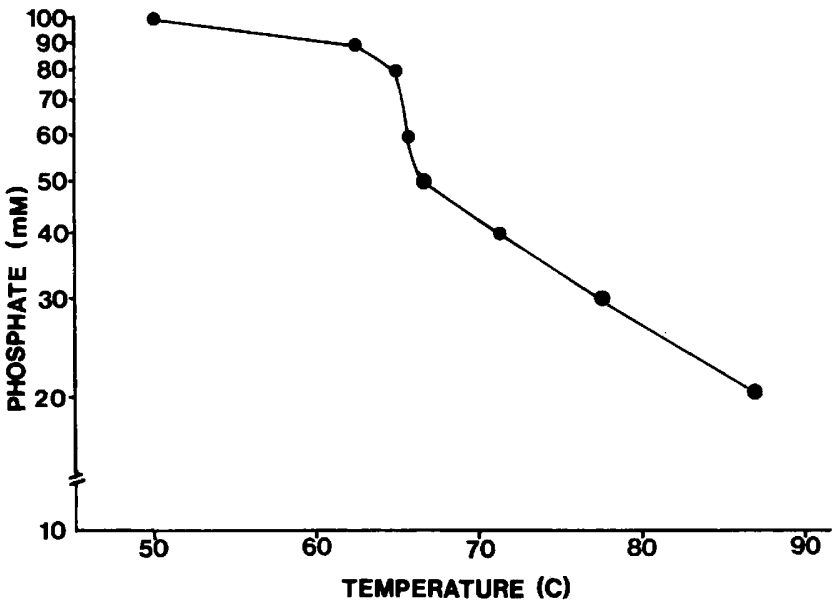

FIG. 2. Window diagram of strain ArI4 DNA obtained by using potassium phosphate buffer (concentration range 20 to $100 \mathrm{mM}$ ) made in $50 \%$ formamide. The $T_{m(e)}$ was plotted for each concentration of buffer on a logarithmic scale. 


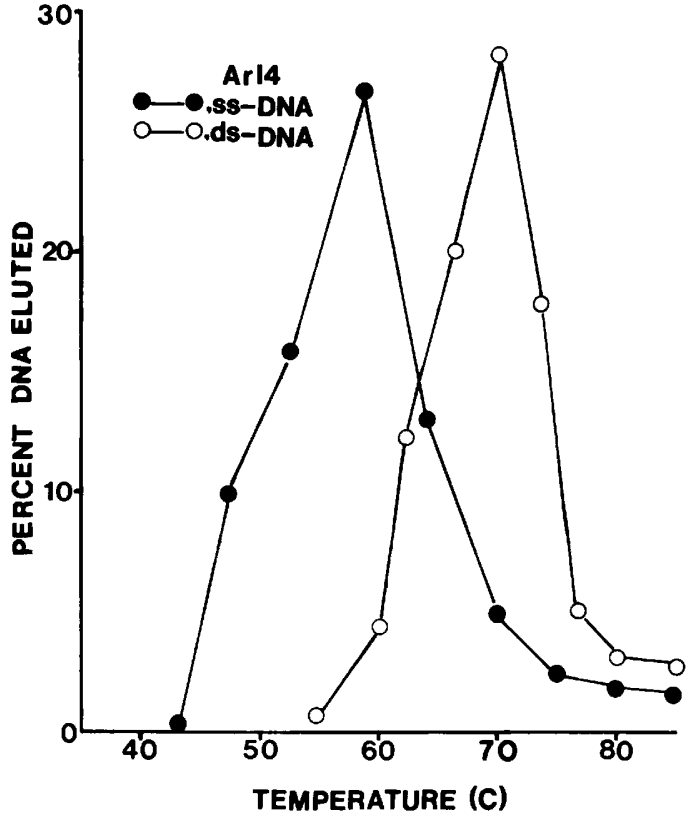

FIG. 3. Thermal elution profiles of strain ArI4 dsDNA and ssDNA with $60 \mathrm{mM}$ potassium phosphate buffer made in $50 \%$ formamide.

and urea, among others) can be used either as a buffer system for hybridization (23) or as an elution buffer (29). The latter method was chosen because a reduced reassociation rate in the organic solvent system would require that the whole reaction system be recharacterized (13). To determine the thermal elution conditions under which elution of the duplex from the hydroxyapatite column really corresponded to strand separation of the duplex, a partial window diagram (Fig. 2) was constructed as described above. Only those concentrations giving a vertical line in Fig. 2 (namely, from 50 to $80 \mathrm{mM}$ ) could be used for thermal elution studies, and $60 \mathrm{mM}$ was chosen. Under these conditions, $50 \%$ of the homologous strain ArI4 duplex was eluted at $66^{\circ} \mathrm{C}$.

The ability of the new elution buffer to distinguish ssDNA from dsDNA was tested by using strain ArI4 DNA. As shown in Fig. 3, there was no clear-cut temperature at which the two could be distinguished since ssDNA was not eluted completely until $75^{\circ} \mathrm{C}$, whereas dsDNA was eluted over a broad range (from 60 to $80^{\circ} \mathrm{C}$ ). However, $60^{\circ} \mathrm{C}$ was chosen to elute ssDNA with the new buffer system, because only $5 \%$ of the dsDNA eluted at that temperature and more than $80 \%$ of the ssDNA eluted. At $65^{\circ} \mathrm{C}$, more than $90 \%$ of the ssDNA eluted, but about $40 \%$ of the dsDNA eluted at that temperature. Thus, $60^{\circ} \mathrm{C}$ appeared to be the optimum temperature for separating ssDNA and dsDNA in this system.

$T_{m(e)}$ values were obtained graphically by plotting the cumulative percentage of DNA eluted at each elution temperature on a linear scale and obtaining the midpoint of the transition from the plot. The following three representative duplexes are shown to demonstrate their thermal elution profiles: strain ArI4 $\times$ strain ArI4, representing a homologous duplex; strain ArI $4 \times$ strain $\mathrm{ACN} 1^{\mathrm{AG}}$, representing a high-homology duplex; and strain ArI4 $\times$ strain D11, representing a low-homology duplex. As shown in Fig. 4, where the ordinate is plotted on a linear scale, the elution profiles of the homologous and high-homology duplexes were sigmoidal, indicating little mismatch in their duplexes; $T_{m(e)}$ values were obtained easily from these graphs. On the other hand, low-homology duplexes produced more complex elution profiles, suggesting a higher degree of mismatch in these duplexes; $T_{m(e)}$ values were not easily obtained from the graph. $T_{m(e)}$ values were also obtained from the elution profile plotted on normal probability paper (15), on which data points for homologous and high-homology duplexes fell on a straight line, whereas points for low-homology duplexes fell on two different lines (data not shown). $T_{m(e)}$ values obtained by these two methods did not differ significantly from each other (data not shown).

Table 5 summarizes the results of our thermal elution studies. The $T_{m(e)}$ values for homologous duplexes were $67.8^{\circ} \mathrm{C}$ for strain ArI4 DNA and $66.2^{\circ} \mathrm{C}$ for strain EuIla DNA. The differences in $T_{m(e)}$ values between homologous and heterologous reactions $\left[\Delta T_{m(e)}\right]$ are also shown. $\Delta T_{m(e)}$ is closely correlated with mismatch. The mean $\Delta T_{m(e)}$ value of high-homology DNA duplexes (homology more than $60 \%$ ) was $3.2^{\circ} \mathrm{C}$, whereas that of low-homology DNA duplexes (homology less than $40 \%$ ) was $4.5^{\circ} \mathrm{C}$, indicating 3 and $5 \%$ mismatches in the duplexes, respectively. According to a widely used convention, a $1^{\circ} \mathrm{C}$ decrease in thermal stability is estimated to reflect a $1 \%$ mismatch in a duplex (9). In Fig. 5 , another presentation of thermal elution is shown in which the percentage of DNA eluted at each elution temperature is plotted on a linear scale instead of as cumulative percentages, as in Fig. 4. The temperature for peak elution of each duplex fell within the range from 63.5 to $67.5^{\circ} \mathrm{C}$, despite wide differences in the homology values.

\section{DISCUSSION}

As a first step in the characterization of the Frankia genome, the base compositions of the DNAs of 12 Frankia isolates were reported (1). The base compositions of seven additional isolates have now been measured by the thermal denaturation method (data not shown). The guanine-pluscytosine contents for these additional strains ranged from 66.6 to $68.3 \mathrm{~mol} \%$. These values are lower than the previ-

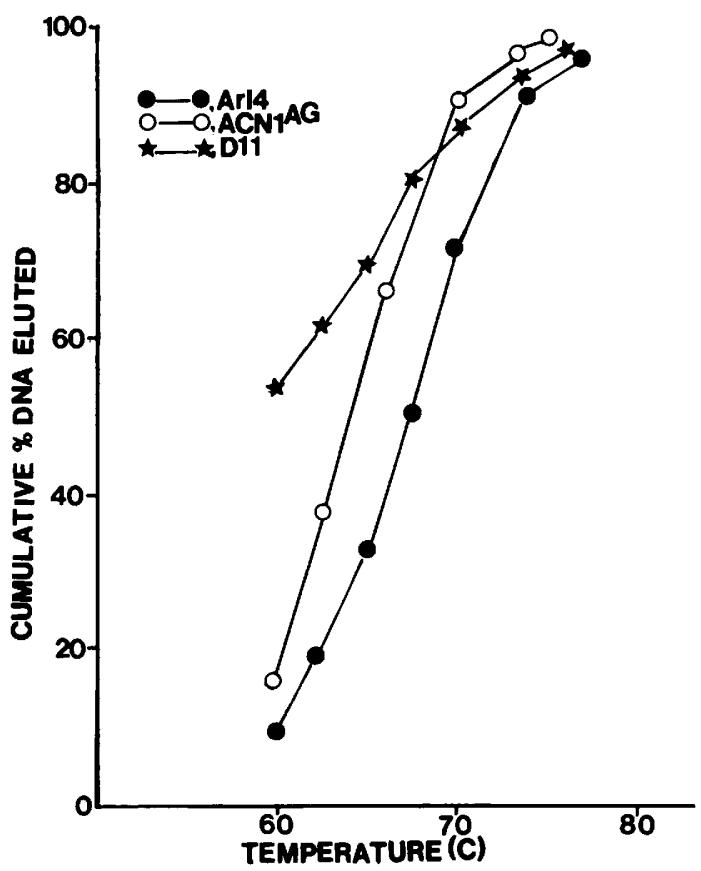

FIG. 4. Thermal elution curves of duplexes formed by strains $\mathrm{ArI} 4, \mathrm{ACN} 1{ }^{\mathrm{AG}}$, and D11 with strain ArI4 at $74.5^{\circ} \mathrm{C}$ on a linear plot. 
ously reported values of 68.4 to $72.1 \mathrm{~mol} \%$, which are above the midpoint of the range of base compositions for members of the order Actinomycetales (53 to $78 \mathrm{~mol} \%$ ) (12).

The purpose of the DNA reassociation kinetics experiments was to measure genome sizes based on kinetic complexity. The mean genome molecular weight of two Frankia isolates was $7.1 \times 10^{9}$, or about 2.5 times the molecular weight of the $E$. coli genome. This value is in the higher range of the known genome molecular weights of other actinomycetes $\left(2.0 \times 10^{9}\right.$ to $\left.7.0 \times 10^{9}\right)(8)$, but smaller than the genome molecular weights of yeasts which have genomes about three times bigger than the $E$. coli genome and near the lower limit for eucaryotic fungal genomes (17).

Genetic relatedness among Frankia isolates was investigated by measuring the quality of hybrid duplexes, as well as the extent of hybrid formation. Frankia isolates were divided into two major groups on the basis of our results. Based on their homology values with strain ArI4 DNA, the genogroup 1 strains exhibited high levels of homology (average, $80 \%$ ), whereas the 10 additional strains tested showed low levels of homology (less than 29\%). The choice of strains for use in preparing DNA probes was arbitrary; strain ArI4 proved to be useful for this purpose, but strain EuIla did not turn out to be a good choice, in the sense that none of the isolates exhibited more than 33\% homology with strain EuIla. With new probe strains, strains CaI1 and G2, at least three additional homology groups were identified. Complete characterization of the levels of DNA relatedness in this group will undoubtedly require the use of several additional probe strains.

The relationship among Frankia isolates revealed by this study is consistent with, but goes beyond, that suggested by other studies. Based on the unique morphology of their sporangia and vesicles and their common cell wall type (type III) and phospholipid pattern (type PI), all of the isolates

TABLE 5. Thermal elution study of the hybrids formed at $74.5^{\circ} \mathrm{C}$

\begin{tabular}{|c|c|c|c|c|}
\hline \multirow{2}{*}{ Strain } & \multicolumn{2}{|c|}{$\begin{array}{l}\text { Hybridization with } \\
\text { strain Arl4 }\end{array}$} & \multicolumn{2}{|c|}{$\begin{array}{l}\text { Hybridization with } \\
\text { strain EuIla }\end{array}$} \\
\hline & $\begin{array}{l}T_{m(e)} \\
\left({ }^{\circ} \mathrm{C}\right)^{a}\end{array}$ & $\begin{array}{l}\Delta T_{m\left(t^{\prime}\right)} \\
\left({ }^{\circ} \mathrm{C}\right)^{b}\end{array}$ & $\begin{array}{l}T_{m(e)} \\
\left({ }^{\circ} \mathrm{C}\right)^{4}\end{array}$ & $\begin{array}{l}\Delta T_{m\left(c^{\prime}\right)} \\
\left({ }^{\circ} \mathrm{C}\right)^{b}\end{array}$ \\
\hline \multicolumn{5}{|l|}{ Genogroup 1} \\
\hline Arl 4 & 67.8 & & 64.5 & 1.7 \\
\hline $\mathrm{ARbN} 4 \mathrm{~b}$ & 65.5 & 2.3 & 63.5 & 2.7 \\
\hline AirI1 & 65.3 & 2.5 & & \\
\hline $\mathrm{ACN} 1^{\mathrm{AG}}$ & 65.7 & 2.1 & & \\
\hline Avcl1 & 65.3 & 2.5 & & \\
\hline AGN1g & 64.7 & 3.1 & & \\
\hline $\mathrm{AGN1}_{\mathrm{EXO}}{ }^{\mathrm{AG}}$ & 64.0 & 3.8 & & \\
\hline MPI1 & 63.4 & 4.4 & & \\
\hline CpI1 & 62.7 & 5.1 & 60.8 & 5.4 \\
\hline \multicolumn{5}{|l|}{$\begin{array}{l}\text { Strains not in } \\
\text { genogroup } 1\end{array}$} \\
\hline Eulla & 64.7 & 3.1 & 66.2 & \\
\hline Airl2 & 62.4 & 5.4 & 60.5 & 5.7 \\
\hline Cal1 & 62.2 & 5.6 & 64.6 & 1.6 \\
\hline D11 & 62.4 & 5.4 & 59.6 & 6.6 \\
\hline PtI1 & 60.7 & 7.1 & 58.8 & 7.4 \\
\hline G2 & 64.0 & 3.8 & 60.2 & 6.0 \\
\hline $\mathrm{EAN} 1^{\mathrm{EA}}$ & 66.5 & 1.3 & & \\
\hline EAN1 $1_{P E C}{ }^{E A}$ & 64.2 & 3.6 & & \\
\hline EUN1fS20 & 61.4 & 6.4 & & \\
\hline EUN1wb & 65.2 & 2.6 & & \\
\hline
\end{tabular}

${ }^{a} T_{m(e)}$ was the temperature at which one-half of the DNA bound to hydroxyapatite was eluted.

${ }^{b} \Delta T_{m\left(e^{2}\right)}$ was the difference between the $T_{m\left(e^{\circ}\right)}$ for the homologous reaction and the $T_{m(e)}$ for the heterologous reaction.

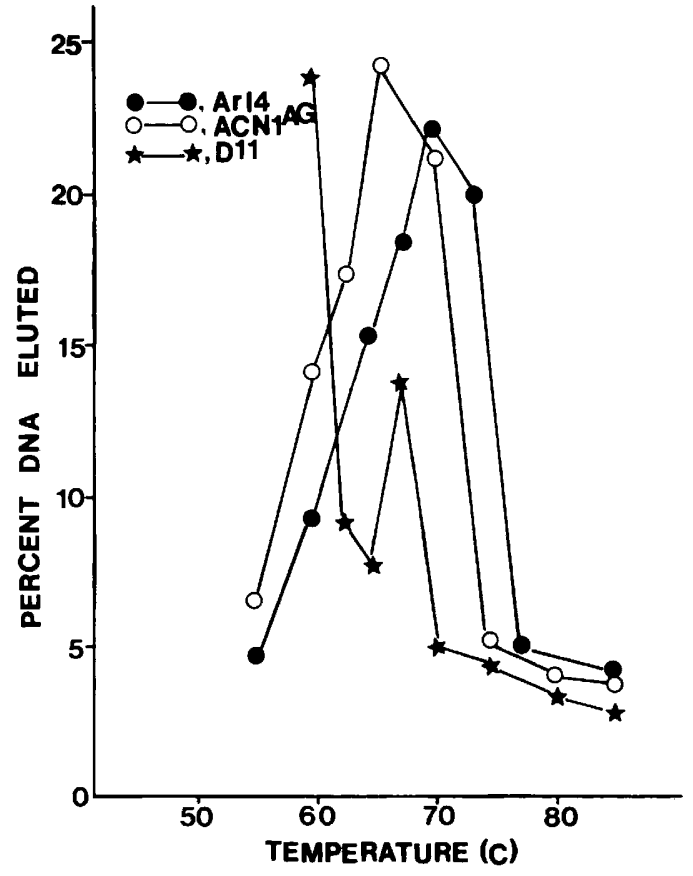

FIG. 5. Thermal elution profiles of duplexes formed by strains $\mathrm{ArI} 4, \mathrm{ACN} 1^{\mathrm{AG}}$, and D11 with strain ArI4 at $74.5^{\circ} \mathrm{C}$.

examined belong to a single genus, Frankia. This conclusion was supported by the small differences $(5.5 \mathrm{~mol} \%)$ in the guanine-plus-cytosine contents of their DNAs. Two major groups which had been suggested by serological, physiological, and cross-inoculation studies were also identified based on differences in DNA homology values $(80$ versus $29 \%$ with strain ArI4). So far, physiological groupings correspond to genogroupings, although it remains to be seen whether the reverse is true, because five strains from genogroup I and

TABLE 6. Present status of Frankia groupings

\begin{tabular}{|c|c|c|c|c|c|}
\hline Strain & Host genus & $\begin{array}{c}\text { Host } \\
\text { compati- } \\
\text { bility } \\
\text { group }^{a}\end{array}$ & $\begin{array}{l}\text { Sero- } \\
\text { group }\end{array}$ & $\begin{array}{l}\text { Physio- } \\
\text { logical } \\
\text { group }\end{array}$ & Genogroup \\
\hline Airl1 & Alnus & 1 & I & B & 1 \\
\hline CpI1 & Comptonia & 1 & I & B & 1 \\
\hline MpI1 & Myrica & 1 & I & B & 1 \\
\hline $\mathrm{ACN} 1^{\mathrm{AG}}$ & Alnus & 1 & & B & 1 \\
\hline ArI4 & Alnus & 1 & I & & 1 \\
\hline Avcll & Alnus & 1 & I & & 1 \\
\hline $\mathrm{ARbN} 4 \mathrm{~b}$ & Alnus & 1 & & & 1 \\
\hline AGN1g & Alnus & 1 & & & 1 \\
\hline $\mathrm{AGN1}_{\mathrm{EXO}}{ }^{\mathrm{AG}}$ & Alnus & & & & 1 \\
\hline G2 & Casuarina & & II & A & 2 \\
\hline D11 & Casuarina & & II & A & 2 \\
\hline Airl2 & Alnus & 1 & II & A & $\mathrm{N}$ \\
\hline EuIla & Elaeagnus & 2 & II & A & $\mathrm{N}$ \\
\hline PtI1 & Purshia & 2 & II & A & $\mathrm{N}$ \\
\hline CaI1 & Ceanothus & & II & A & $\mathrm{N}$ \\
\hline EAN1 $1_{P E C}{ }^{E A}$ & Elaeagnus & & & & $\mathrm{N}$ \\
\hline $\mathrm{EAN} 1{ }^{\mathrm{EA}}$ & Elaeagnus & & & & $\mathrm{N}$ \\
\hline EUN1wb & Elaeagnus & & & & $\mathrm{N}$ \\
\hline EUN1fS20 & Elaeagnus & & & & $\mathrm{N}$ \\
\hline
\end{tabular}

a See reference 2 .

${ }^{b}$ See reference 19

c Genogroup 1 strains have high levels of homology with strain ArI4. N, No genogroup assigned. 
four strains not homologous with strain ArI4 have not been tested by physiological criteria (Table 6). Our data also provide insight into the relationships among the isolates, not only within each group but also between groups, which were not obtained by other studies. According to the Becking system of classification (6), which was based largely on cross-inoculation studies with crushed nodule inocula, isolates belonging to genogroup I would have been classified as Frankia alni or Frankia brunchorstii, depending on the host genera. However, we found high levels of homology (more than $80 \%$ ) among the isolates from both host plants, and other workers have demonstrated that cross-inoculation within this group does occur, suggesting that they should be considered a single species. Moreover, one strain from Alnus, strain AirI2, which also would have been given the name $F$. alni, is at most distantly related to another isolate from the same species, strain AirIl. Strains belonging to genogroup 1 and all of the other strains tested are quite different from each other, having less than $39 \%$ homology. Finally, at least three subgroups [subgroups G2(D11), PtI1, and EuIla] were identified among the isolates outside genogroup 1 by DNA homology tests in which three probe strains from three different host genera were used (Table 4).

Thermal elution studies to measure the quality of the hybrid duplexes revealed interesting results. Despite wide differences in their DNA homology values ( 80 versus $25 \%$ ), the difference in $\Delta T_{m(e)}$ was very small (3.2 versus $\left.4.5^{\circ} \mathrm{C}\right)$. In some taxonomic groups, there is a good correlation between percent homology and the thermal stability of duplexes, with about $1{ }^{\circ} \mathrm{C}$ decrease in $T_{m(e)}$ corresponding to a $5 \%$ difference in interspecies homology value (14). Thus, the small difference in $\Delta T_{m(e)}$ which we observed indicated that duplexes bound to the hydroxyapatite column were quite stable regardless of the overall homology values. Additionally, peak elution of all of the hybrid duplexes occurred within a small range $\left( \pm 2^{\circ} \mathrm{C}\right)$. The fact that hybrid duplexes between strains belonging to genogroup 1 had a small $\Delta T_{m(e)}$ value indicates that there has been relatively little divergence in the entire genomes of these strains. The small $\Delta T_{m(e)}$ value of hybrid duplexes among all other strains indicates that although the largest portions of the genomes exhibit a great deal of divergence, small portions of the genome are highly conserved among all of the strains. The nature of the conserved section of the genomes (approximately 10\%) is not known. Genes for ribosomal ribonucleic acids are known to be very conserved among different bacteria (28). Genes for nitrogen fixation activity are also known to be conserved among nitrogen-fixing organisms (27). It should be helpful in the characterization of the conserved segment of the Frankia genome to elute bound duplexes and compare DNA homology or to probe Frankia genomes with cloned genes for ribosomal ribonucleic acid, for nitrogen fixation, and for other conserved functions.

It is evident from this study that the genetic diversity among frankiae is large indeed. The use of four probe strains revealed the presence of at least four possible genogroups. For practical purposes, DNA homology data should be correlated with other biological properties that can be detected more easily. Unfortunately, it is not yet possible to make such a correlation because only limited biological characterization has been accomplished on the strains used in this study. The potential for using DNA homology data as a means of grouping isolates has been demonstrated here, and as more isolates become available for study it is likely that this approach will provide the basis for a comprehensive framework for the classification of Frankia.

\section{ACKNOWLEDGMENTS}

We thank the following people who provided valuable isolates for our research: M. P. Lechevalier (Rutgers University), D. Baker (Kettering Research Laboratory), and M. Lalonde (Laval University).

Support for this work was provided by grant BSR83-0678 from the National Science Foundation.

\section{LITERATURE CITED}

1. An, C. S., J. H. Wills, W. S. Riggsby, and B. C. Mullin. 1983. Deoxyribonucleic acid base composition of 12 Frankia isolates. Can. J. Bot. 61:2859-2862.

2. Baker, D. 1982. A cumulative listing of isolated frankiae, the symbiotic nitrogen-fixing actinomycetes. Actinomycetes 17:35-42.

3. Baker, D., W. L. Pengelly, and J. G. Torrey. 1981. Immunological analysis of relationships among the isolated frankiae (Actinomycetales). Int. J. Syst. Bacteriol. 31:148-151.

4. Baker, D., and J. G. Torrey. 1979. The isolation and cultivation of actinomycetous root nodule endophytes, p. 38-56. In J. C. Gordon, C. T. Wheeler, and D. A. Perry (ed.), Symbiotic nitrogen fixation in the management of temperate forests. Forestry Research Laboratory, Oregon State University, Corvallis.

5. Baker, D., and J. G. Torrey. 1980. Characterization of an effective actinorhizal microsymbiont, Frankia sp. Avcll (Actinomycetales). Can. J. Microbiol. 26:1066-1071.

6. Becking, J. H. 1974. Frankiaceae, p. 701-708. In R. E. Buchanan and N. E. Gibbons (ed.), Bergy's manual of determinative bacteriology, 8th ed. The Williams \& Wilkins Co., Baltimore.

7. Berry, A., and J. G. Torrey. 1979. Isolation and characterization in vitro and in vivo of an actinomycetous endophyte from Alnus rubra Bong, p. 69-83. In J. C. Gordon, G. T. Wheeler, and D. A. Perry (ed.), Symbotic nitrogen fixation in the management of temperate forests. Forest Research Laboratory, Oregon State University, Corvallis.

8. Bradley, S. G., L. W. Enquist, and H. E. Scribner III. 1978. Heterogenetiy among deoxyribonucleotide sequences of Actinomycetales, p. 207-224. In E. J. Freerksen, I. Tarnok, and J. H. Thumin (ed.), Genetics of the Actinomycetales. Gustav Fischer Verlag, Stuttgart.

9. Brenner, D. J., G. R. Fanning, K. E. Johnson, R. V. Citarella, and S. Falkow. 1969. Polynucleotide sequence relationship among members of the Enterobacteriaceae. J. Bacteriol. 98:637-650.

10. Britten, R. J., and D. E. Kohne. 1968. Repeated sequences in DNA. Science 161:529-540.

11. Callaham, D., P. De Tredici, and J. G. Torrey. 1978. Isolation and cultivation in vitro of the actinomycete causing root nodulation in Comptonia. Science 199:899-902.

12. Goodfellow, M., and D. E. M. Minnikin. 1981. Classification of nocardioform bacteria, p. 7-16. In K. P. Schaal and G. Pulverer (ed.). Actinomycetes. Proceedings of the Fourth International Symposium on Actinomycete Biology. Gustav Fischer Verlag, New York.

13. Hutton, J. R. 1977. Renaturation kinetics and thermal stability of DNA in aqueous solutions of formamide and urea. Nucleic Acids Res. 4:3537-3555.

14. Johnson, J. L. 1973. Use of nucleic acid homologies in the taxonomy of anaerobic bacteria. Int. J. Syst. Bacteriol. 23: 308-315.

15. Knittel, M. D., C. H. Black, W. E. Sandine, and D. K. Fraser. 1968. Use of normal probability paper in determining thermal melting values of deoxyribonucleic acid. Can. J. Microbiol. 14:239-245.

16. Lalonde, M., and E. H. Calvert. 1979. Production of Frankia hyphae and spores as an infective inoculant for Alnus species, p. 95-100. In J. C. Gordon, C. T. Wheeler, and D. A. Perry (ed.), Symbiotic nitrogen fixation in the management of temperate forests. Forest Research Laboratory, Oregon State University, Corvallis.

17. Lauer, G. D., T. M. Roberts, and L. C. Klotz. 1977. Determi- 
nation of the nuclear DNA content of Saccharomyces cerevisiae and implications for the organization of DNA in yeast chromosomes. J. Mol. Biol. 114:507-526.

18. Lechevalier, M. P., D. Baker, and F. Horriere. 1983. Physiology, chemistry, serology and infectivity of two Frankia isolates from Alnus incarna (L) subsp. rugosa. Can. J. Bot. 61:2826-2833.

19. Lechevalier, M. P., and H. A. Lechevalier. 1984. Taxonomy of Frankia, p. 575-582. In L. Ortiz-Ortiz, L. J. Bojalil, and V. Yakoleff (ed.), Biological, biochemical and biomedical aspects of Actinomycetes. Academic Press, Inc., New York.

20. Lewin, B. 1980. Gene expression, vol. 2. John Wiley \& Sons, Inc., New York.

21. Martinson, H. G., and E. B. Wagenear. 1974. Thermal elution chromatography and the resolution of nucleic acids on hydroxylapatite. Anal. Biochem. 61:144-154.

22. Martinson, H. G., and E. B. Wagenear. 1977. Thermal elution chromatography of nucleic acids on hydroxyapatite. Biochim. Biophys. Acta 474:445-455.

23. McConaughy, R. L., C. D. Laird, and B. J. McCarthy. 1969. Nucleic acid reassociation in formamide. Biochemistry 8 :
3289-3297.

24. Pearson, W. R., E. H. Davidson, and R. J. Britten. 1977. A program for least square analysis of reassociation and hybridization data. Nucleic Acids Res. 4:1727-1737.

25. Rigby, P.W., M. Dieckmann, C. Rhodes, and P. Berg. 1977. Labeling deoxyribonucleic acid to high specific activity in vitro by nick translation with DNA polymerase 1 . J. Mol. Biol. 113:237-251

26. Riggsby, W. S., L. J. Torres-Bauza, J. W. Wills, and T. M. Townes. 1982. DNA content, kinetic complexity and the ploidy question in Candida albicans. Mol. Cell. Biol. 2:853-862.

27. Ruvkun, G. B., and F. M. Ausubel. 1980. Interspecies homology of nitrogenase genes. Proc. Natl. Acad. Sci. U.S.A. 77:191-195.

28. Schleifer, K. H., and E. Stackebrandt. 1983. Molecular systematics of procaryotes. Annu. Rev. Microbiol. 37:143-187.

29. Smith, M. J., B. R. Hough, M. E. Chamberlin, and E. H. Davidson. 1974. Repetitive and non-repetitive sequences in sea urchin heterogeneous nuclear RNA. J. Mol. Biol. 85:103-126.

30. Wetmur, J. G., and N. Davidson. 1968. Kinetics of renaturation of DNA. J. Mol. Biol. 31:349-370. 